\title{
Reported Malnutrition Prevention Practices in Primary Schools in Ido Local Government Area of Ibadan, Oyo State, Nigeria
}

\author{
Mary Damilola Adu ${ }^{1,}$, , Ikeoluwapo Oyeneye Ajayi ${ }^{1}$, Kayode Titus Adu ${ }^{2}$ \\ ${ }^{1}$ Department of Epidemiology and Medical Statistics, Faculty of Public Health, University of Ibadan, Ibadan, Nigeria \\ ${ }^{2}$ School of Land and Food, Tasmania Institute of Agriculture, University of Tasmania, Hobart, Australia \\ Email address: \\ adumdammy@gmail.com (M. D. Adu), ikeajayi2003@yahoo.com (I. O. Ajayi), aduktus@gmail.com (K. T. Adu)
}

\section{To cite this article:}

Mary Damilola Adu, Ikeoluwapo Oyeneye Ajayi, Kayode Titus Adu. Reported Malnutrition Prevention Practices in Primary Schools in Ido Local Government Area of Ibadan, Oyo State, Nigeria. International Journal of Elementary Education. Vol. 4, No. 5, 2015 , pp. 93-100. doi: $10.11648 /$ j.ijeedu.20150405.11

\begin{abstract}
Previous studies on all aspects of school health programs gave only little information on nutrition and physical education despite their importance characteristics of; enduring, effective and economical interventions towards the prevention of malnutrition. This study gave a comprehensive report on nutrition and physical education in primary schools. Nutrition teaching aids along with meal policies at schools were also elucidated. This study was conducted in 2010 among 387 teachers selected by multistage sampling from 26 public and 13 private primary schools in 3 semi-urban communities in Ibadan, Southwest Nigeria. Using a structured questionnaire, the researchers collected data regarding the methods of disseminating nutrition and physical education at schools, time allocation with perceived barriers to their proper implementation. Availability of nutrition teaching aids and meal policies at respondent schools were also documented. Data collected was analysed using SPSS version 16 statistical software. The result showed that larger percentage of the respondents integrated nutrition lessons to a great extent with the home economics $(212,54.8 \%)$, agricultural sciences $(189,48.8 \%)$, health and physical education $(210$, $54.2 \%$ ) courses. Insufficient instructional time and fund were mentioned as major barriers to effective implementation of both nutrition and physical education. The reported time spent on nutrition education at public schools was significantly lower than that of private ones $(\mathrm{p}=0.000, \mathrm{t}=4.30)$, while, on the other hand, the time reported to be invested by the public school teachers on sports activities by their pupils was significantly higher than that by the private school teachers $(\mathrm{p}=0.000, \mathrm{t}=5.83)$. Regarding meal policies; (227) $80.5 \%$ of teachers at public schools compared to $57(54.3 \%$ ) at private ones responded affirmatively to the policy on initial medical screening of food vendors prior to their employment while $251(89.0 \%)$ from public school had policy on the assessment of the appearance of food provided by food vendors as compared to $68(64.8 \%)$ from private schools $\left(X^{2}=26.91 ; p=0.000\right.$, and $X^{2}=31.053 ; p=0.000$ respectively). Similarly, 254(90.1\%) of respondents at public schools compared to 67(63.8\%) in private ones indicated that their school ensured that varieties of food are provided for pupils by the food vendors. $\left(X^{2}=37.302 ; \mathrm{p}=0.000\right)$. Reported time spent on nutrition and physical education at schools is lower than the recommended standard. Inadequate time and funding were barriers to effective nutrition and physical education within the school system. Routine medical screening for food vendors is absent in most of the schools.
\end{abstract}

Keywords: Primary Schools, Physical Education, Nutrition Education, Meal Policies

\section{Introduction}

Nutrition education, school health services, counseling and social support programs, school gardens, feeding programs ${ }^{[1]}$., food services and physical education are all the components of School Health Programs targeted at preventing malnutrition in children ${ }^{[1,2]}$. Upon evaluation of all the aspects of School Health Programs, nutrition education has been found to be of utmost importance because it is one of the most enduring, effective and economical interventions ${ }^{[1]}$. Nutrition and dietary behaviour education are part of the health education curriculum and have been required to be taught at the elementary, middle and high school levels ${ }^{[3]}$. School - based nutrition education 
has been shown to contribute significantly to the basis of the prosperous societies, as it provides people with the knowledge, skills and motivation to make wise dietary and lifestyle choices, thus building a strong basis for a healthy and active life ${ }^{[1]}$. Studies ${ }^{[1,4]}$ have noted that schools are ideal settings for promoting healthy eating as they reach most children for a number of years on regular basis and at a critical age when eating habits and attitudes are being established. Schools have an important environmental influence on the dietary behaviour of children and young adolescents ${ }^{[5,6]}$, as approximately $97 \%$ of children and adolescents will probably be enrolled in school, where they spend majority of their day, therefore the school environment can either encourage or hinder healthy eating. Eating patterns are more likely to improve when changes in the school environment are integrated with classroom nutrition education ${ }^{[7]}$. Nutrition education has been established as an effective way in which to confront malnutrition and food-related diseases ${ }^{[8]}$.

On the other hand, physical education in schools provides the setting for regular and structured physical activity participation, it teaches skills that are needed for a lifetime physical activity. To this end, justification for physical education in school curriculum is that it contributes to children's health and fitness $[9,10]$.

Health patterns including nutrition and physical activity behaviours are solidified by the time a child reaches grade six (primary 6), making early education in these areas critical to the development of healthy lifestyles [11]. Adequate measures which includes good dietary practices (such as nutrition education, regular medical screening for food vendors, assessment of food quality and appearance) must be put in place to prevent malnutrition ${ }^{[12]}$; also school-based physical education and exercise must be encouraged more because obesity is on the increase among school children in many nations of the world including Nigeria ${ }^{[13,14]}$.

Previous studies in Nigeria have found inadequacy of duration/time allocated to subjects containing nutrition and health issues as a critical factor that affects health instruction in schools ${ }^{[15]}$. Despite the important role of nutrition and physical education at improving the health of school children, these have been described as a neglected component of the School Health Program ${ }^{[16]}$. This neglection coupled with lack of infrastructure and instructional materials have been identified as problems responsible for the poor status of the instructional components of Health Programs in the Nigerian school system ${ }^{[15]}$. Studies that have elucidated all aspects of school health programs together most of the times provide little information on these very crucial aspects - nutrition and physical education $[15,16,17]$. To date no study has provided comprehensive reports on these aspects of health programs targeted at preventing malnutrition in children. The study area is of special interest because it is semi-urban in nature and at the time of this study it is majorly dominated by peasant farmers and petty traders; this characteristics of limited economic resources have a high probability of predisposing the children to malnutrition.

This study thus becomes highly imperative because it aims at providing substantial data on; the status of some key elements necessary for the effective implementation of nutrition and physical education and the available meal policies within the school system. The first purpose of this study is to provide information on the time allotted to nutrition and physical education and the extent to which they are integrated with some subjects. A second purpose is to inquire about the perceived barriers to nutrition and physical education and availability of nutrition teaching aids at the selected schools. A third purpose is to investigate the availability of meal policies such as medical screening for food vendors, assessing the appearance of food provided by food vendors and ensuring that variety of food is provided for pupils by food vendors. In achieving these aims the following research questions were raised

- What is the time allotted to nutrition and physical education in primary schools in Ido Local Government Area of Oyo State?

- To what extent are nutrition lessons integrated with some courses offered in the schools?

- What are the perceived barriers to effective nutrition and physical in the schools?

- Are teaching aids available for teaching nutrition in the schools?

- Do the schools have meal policies basically in form of medical screening for food vendors, assessment of food appearance and ensuring varieties of food is provided by food vendors?

\section{Methods}

\subsection{Study Area, Design and Sampling}

The study was conducted among teachers of primary schools in Ido Local Government Area (LGA) of Oyo State, Nigeria. The LGA is inhabited mainly by Yoruba of the South Western part of Nigeria. The inhabitants are mostly farmers and petty traders.

The study was a school-based cross-sectional descriptive type conducted between February and March 2010, which was the mid period in the second term of the school calendar year. It involved teachers from 26 public and 13 states approved private primary schools selected by multistage sampling. Consideration was given to the timing and the conduct of the study so that normal teaching periods were not interrupted.

\subsection{Instruments}

The structured questionnaire was designed based on the review of the related literature. One of the authors visited the state ministry of education to inquire about the components of nutrition and physical education; and meal policies expected in primary schools in the state, and this was inculcated in the questionnaire. 
In order to ensure the content validity of the instrument, the questionnaire was referred to 3 experts in the fields of nutrition and physical education for vetting so as to ensure its appropriateness, relevance and clarity and adequacy to meet the objectives of the study. Also, a pretesting of the questionnaire was conducted among twenty teachers in another school not included in the study. Using alpha cronbach's test of SPSS version 16, the reliability of the pretested questionnaires gave an internal consistency of 0.877. This was considered high enough to ensure reliability of the instrument. Following the validity and pretesting, the necessary modifications were made to the instrument to facilitate comprehension on the part of the participants. The instrument was self-administered and only teachers who at the time of data collection taught subjects which included nutrition and physical education were included in the study.

The questionnaire has the sections on availability of various components of nutrition and physical education such as scope and methods used in giving instruction as obtainable in the National Primary Schools' Curriculum (Nigerian Educational Research and Development Council (NERC) ${ }^{[18]}$. The questionnaire sought information about the time spent on nutrition and physical education and the extent to which they were integrated with some subjects. There were also questions on the barriers to effective nutrition and physical education. In addition, the availability of nutrition teaching aids, meal policies such as medical screening for food vendors, assessing the appearance of food provided for the pupils by the food vendors and ensuring that varieties of food is provided for pupils; were also elucidated. It should be noted that questions pertaining to extent to which nutrition education were integrated with some subjects, perceived barriers to effective nutrition and physical education and the status of nutrition aids were assessed with responses on a 4 point Likert scale which includes 'not at all', "small extent", "moderate extent" and "great extent"; this is to allow respondents choose the option that best align with their view.

SPSS version 16.0 statistical software was used for all the analyses. Descriptive statistics such as means, range, standard deviations, percentages as applicable; were used to summarize data. Chi square and student t-tests were used to test for comparison between public and private schools. The differences in observed values were regarded to be statistically significant if the $\mathrm{P}$ value was less than 0.05 .

\subsection{Ethics Consideration}

Ethical approval to conduct the study was given by the Ethical Review Board of the Oyo state Ministry of Health. A written permission was granted by the Ido Local Government Education Authority. Participants were in no way coerced to participate but absolute honesty in answering the questions was solicited. Written informed consent was also obtained from each participant after proper explanation of the whole research process.

\section{Results}

\subsection{Demographic Characteristics of Respondents}

Three hundred and eighty seven teachers accepted to participate. As shown in Table 1, their ages ranged from 20 to 59 years with a mean age of $37.5 \pm 9.1$ years. The highest academic qualification obtained by most of the teachers was National Certificate in Education $(n=228,58.9 \%)$. The respondent's years of experience in teaching profession ranged from 1 to 34 years with a mean of $10.4 \pm 8.2$ years.

Table 1. Demographic characteristics of respondents $(N=387)$.

\begin{tabular}{|c|c|c|}
\hline Demographic Characteristics & $\mathbf{n}$ & $\%$ \\
\hline \multicolumn{3}{|l|}{ Age in year } \\
\hline $20-29$ & 95 & 24.6 \\
\hline $30-39$ & 110 & 28.4 \\
\hline $40-49$ & 146 & 37.7 \\
\hline 50 years and above & 36 & 9.3 \\
\hline \multicolumn{3}{|l|}{ Sex } \\
\hline Male & 130 & 33.6 \\
\hline Female & 257 & 66.4 \\
\hline \multicolumn{3}{|l|}{ Highest Academic Qualification } \\
\hline NCE & 228 & 58.9 \\
\hline Bachelors & 73 & 18.9 \\
\hline Grade II & 17 & 4.4 \\
\hline Masters & 5 & 1.3 \\
\hline Others & 64 & 16.5 \\
\hline \multicolumn{3}{|l|}{ Years of teaching experience } \\
\hline $1-9$ & 207 & 53.5 \\
\hline $10-19$ & 116 & 30.0 \\
\hline $20-29$ & 59 & 15.2 \\
\hline 30 and above & 5 & 1.3 \\
\hline \multicolumn{3}{|l|}{ Type of school } \\
\hline Public & 282 & 72.9 \\
\hline Private & 105 & 27.1 \\
\hline
\end{tabular}

\subsection{Nutrition Education}

\subsubsection{Extent to Which Nutrition Education Are Integrated into Some Subject Areas.}

Teachers in all schools gave nutrition lessons by integration with other subjects. About half, 210 (54.2\%) of the respondents indicated that lessons about nutrition were to a "great extent" taught in the health and physical education subject, while $212(54.8 \%)$ and $189(48.8 \%)$ respondents indicated that to a "great extent" there were lessons on nutrition in the home economics and agricultural science subjects respectively. While $127(32.8 \%)$ respondents indicated that to 'great extent' nutrition education is integrated with social studies subject. Details are presented in table 2 . 
Table 2. Extent to which nutrition lessons were integrated with some subjects. $(N=387)$

\begin{tabular}{|c|c|c|c|c|}
\hline Subjects & $\begin{array}{l}\text { Not at all } \\
\text { n }(\%)\end{array}$ & $\begin{array}{l}\text { To a small } \\
\text { extent } \\
\text { n (\%) }\end{array}$ & $\begin{array}{l}\text { To a moderate } \\
\text { extent } \\
n(\%) \\
\end{array}$ & $\begin{array}{l}\text { To a great } \\
\text { extent } \\
\text { n (\%) } \\
\end{array}$ \\
\hline Physical and Health education & $0(0.0)$ & $85(22)$ & $92(23.8)$ & $210(54.2)$ \\
\hline Social studies & $24(6.2)$ & $69(17.8)$ & $167(43.2)$ & $127(32.8)$ \\
\hline Home economics & $14(3.6)$ & $45(11.6)$ & $116(30.0)$ & $212(54.8)$ \\
\hline Reading language and art & $44(11.4)$ & $68(17.57)$ & $99(25.6)$ & $176(45.5)$ \\
\hline Agricultural Science & $25(6.5)$ & $67(17.3)$ & $106(27.4)$ & $189(48.8)$ \\
\hline
\end{tabular}

\subsubsection{Time Spent on Nutrition Education}

a. Figure 1 shows the average time in minutes (per week) spent on teaching nutrition education to pupils. A mean time of $93.43 \pm 51.33$ was spent with a range of $10-230$ minutes.

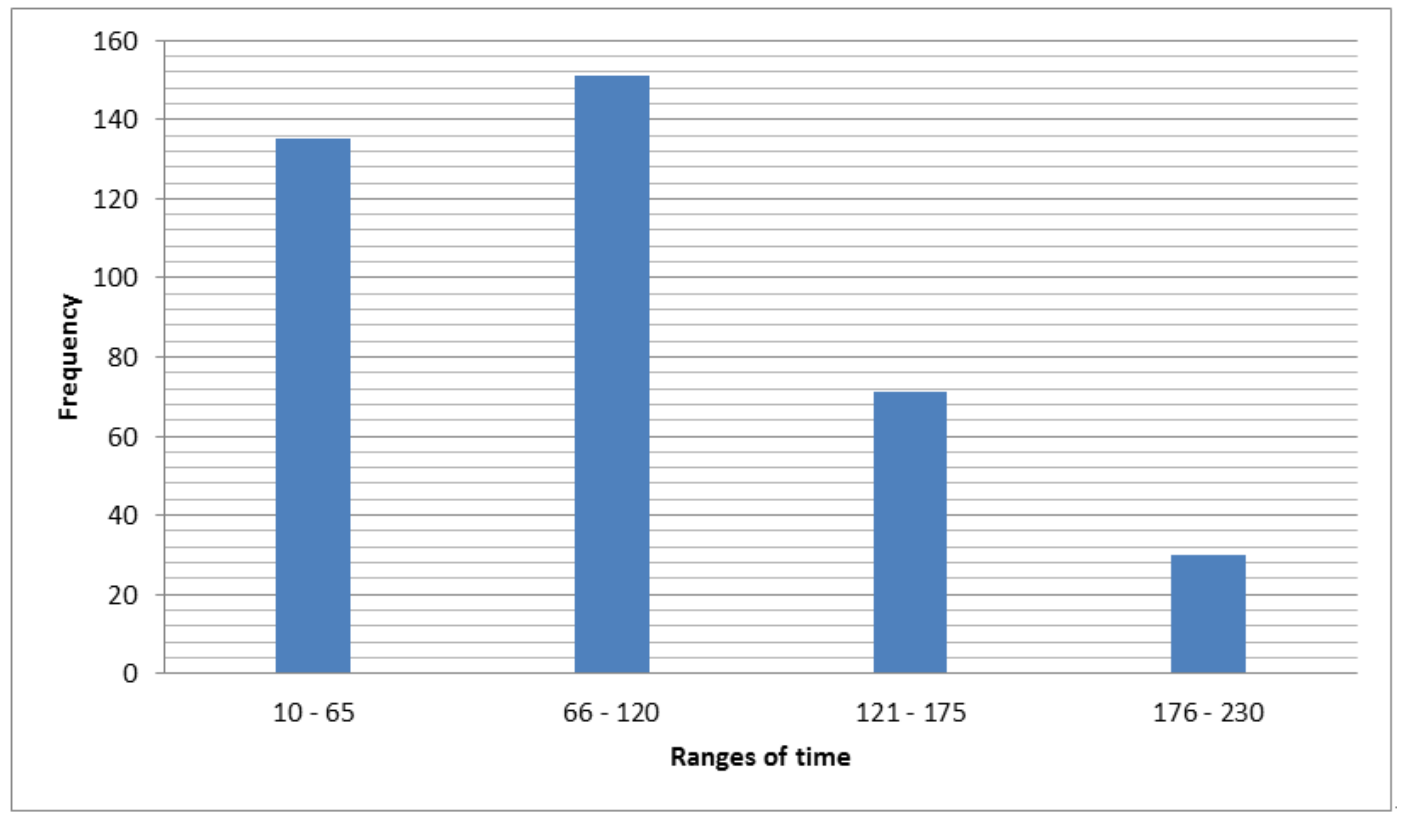

Figure 1. Time spent on nutrition education.

Table 3. Comparison of average time (minutes) spent on nutrition education per week according to the type of school. $N=387$.

\begin{tabular}{lllll}
\hline Type of school & $\overline{\mathbf{X}}$ & SD & $\mathbf{n}$ & $\begin{array}{l}\text { Test statistics } \\
\text { and P value }\end{array}$ \\
\hline Public & 75.44 & 49.63 & 282 & $\mathrm{t}=4.30 ;$ \\
Private & 100.1 & 51.46 & 105 & $\mathrm{p}=.000$ \\
\hline
\end{tabular}

b. Comparison of time spent on nutrition education according to school type.

Table 3 presents the results on comparison of the time spent according to the respondents' school type. This shows that the average time reported by teachers in private schools $(100.1 \pm 51.46)$ was significantly higher than the reported time spent of those in public schools $(75.44 \pm 46.63)$, $(\mathrm{p}=$ $0.000, \mathrm{t}=4.3$ ).

\subsubsection{Barriers to Effective Nutrition Education (Multiple Responses)}

Table 4 presents teachers responses on the barriers to effective nutrition education within their school system.

One hundred and sixty two (41.9\%) and 177 (45.7\%) respondents reported that insufficient instructional time and fund to support nutrition education respectively were to a "great extent" hindrance to effective nutrition education in their schools.

Table 4. Barrier to effective teaching of nutrition education within respondent's school system.

\begin{tabular}{|c|c|c|c|c|}
\hline Barriers & $\begin{array}{l}\text { Not at all } \\
\text { n }(\%)\end{array}$ & $\begin{array}{l}\text { To a small } \\
\text { extent } \\
\text { n (\%) }\end{array}$ & $\begin{array}{l}\text { To a moderate } \\
\text { extent } \\
\text { n }(\%)\end{array}$ & $\begin{array}{l}\text { To a great } \\
\text { extent } \\
\text { n (\%) }\end{array}$ \\
\hline Insufficient instructional time to fit in activities & $26(6.7)$ & $70(18.1)$ & $129(33.3)$ & $162(41.9)$ \\
\hline Insufficient funding to support nutrition education & $49(12.7)$ & $60(15.5)$ & $101(26.1)$ & $177(45.7)$ \\
\hline Lack of administrative approval & $190(49.1)$ & $93(24.0)$ & $72(18.6)$ & $32(8.3)$ \\
\hline $\begin{array}{l}\text { The way the school meal is structured (e.g outside } \\
\text { food vendor, school canteen) }\end{array}$ & $153(39.5)$ & $113(29.2)$ & $92(23.8)$ & $29(7.5)$ \\
\hline
\end{tabular}




\subsubsection{Availability and Status of Nutrition Teaching Aids}

i. Out of the total respondents, only $281(77.6 \%)$ reported the availability of nutrition teaching aids (such as charts, posters, video clips) for teaching their pupils.

ii. The opinions on the status of such teaching aids are presented on Table 5 where a small percentage 27(9.6) and $19(6.8)$ of the respondents thinks to "a great extent" the teaching aids are; appropriate for age and enough for all pupils to use respectively.

Table 5. Status of nutrition teaching aids used for pupils $(N=281)$.

\begin{tabular}{lllll}
\hline Status & $\begin{array}{l}\text { Not at all } \\
\mathbf{N}(\mathbf{\%})\end{array}$ & $\begin{array}{l}\text { To a small } \\
\text { Extent } \\
\mathbf{N}(\mathbf{\%})\end{array}$ & $\begin{array}{l}\text { To a moderate } \\
\text { extent } \\
\mathbf{n}(\mathbf{\%})\end{array}$ & $\begin{array}{l}\text { To a great } \\
\text { extent } \\
\mathbf{n}(\%)\end{array}$ \\
\hline Teaching aids are up to date & $32(11.3)$ & $137(48.8)$ & $76(27.1)$ & $36(12.8)$ \\
$\begin{array}{l}\text { Teaching aids are appropriate For ages } \\
\text { Pupils finds teaching aids appealing }\end{array}$ & $30(10.6)$ & $121(43.1)$ & $103(37.7)$ & $27(9.6)$ \\
There are enough teaching aids for all pupil to use & $84(12.1)$ & $94(33.5)$ & $106(37.7)$ & $47(16.7)$ \\
\hline
\end{tabular}

Table 6. Reported barriers to effective physical education in schools $(N=387)$.

\begin{tabular}{|c|c|c|c|c|}
\hline Barriers & $\begin{array}{l}\text { Not at all } \\
\text { N (\%) }\end{array}$ & $\begin{array}{l}\text { To a small } \\
\text { extent } \\
\text { n (\%) }\end{array}$ & $\begin{array}{l}\text { To a moderate } \\
\text { extent } \\
\text { n }(\%) \\
\end{array}$ & $\begin{array}{l}\text { To a great } \\
\text { extent } \\
\text { n (\%) } \\
\end{array}$ \\
\hline Inadequate sport facilities & $46(11.9)$ & $60(15.5)$ & $114(29.5)$ & $167(43.1)$ \\
\hline Classes for other subjects takes too much time & $163(42.1)$ & $96(24.8)$ & $85(22.0)$ & $43(11.1)$ \\
\hline Insufficient fund to support physical education & $61(15.8)$ & $90(23.3)$ & $107(27.6)$ & $129(33.3)$ \\
\hline Physical education not taken to be important by pupils & $230(59.4)$ & $82(21.2)$ & $47(12.1)$ & $28(7.2)$ \\
\hline
\end{tabular}

\subsection{Physical Education}

\subsubsection{Factors Affecting Physical Education}

A large proportion of the respondent noted inadequate sport facilities $(167,43.1 \%)$ and insufficient funding $129(33.3 \%)$; as factors which to "a great extent" serves as barrier to effective physical education within schools. Detailed results are shown on Table 6.

\subsubsection{Availability and Status of Sport Activities in Schools}

All respondents indicated that their pupils engaged in sporting activities. Their opinion on the level of these sport activities is as follows; 135 (34.9\%) indicated that the sport activities of their pupils was not enough, 81 (20.9\%) expressed total satisfaction while $171(44.1 \%)$ were partially satisfied and expressed the need for further planning of the available sport activities.

\subsubsection{Time Student's Spent on Sport Activities $(n=387)$}

i. The reported average time (minutes) pupils spent on sport activities per week ranges from 20 to 225 minutes with a mean time of $80.94 \pm 39.9$ minutes. Majority, 193 (49.9\%) of the respondents indicated between 20 - 71 minutes, 155 (40.1\%) noted between $72-123$ minutes, 31 (8.0\%) signified between 124 - 175 minutes while a few, 8 (2.1\%) respondents indicated that their pupils spent between $176-$
225 minutes on sport activities per week.

ii. Comparison of the mean time per week spent on sport activities between school types was done using independent sample t- test. There was a significant difference $(\mathrm{p}<.05)$ in the average time with more time 87.87. \pm 41.27 spent at the public schools as compared to $62.33 . \pm 28.86$ at private ones. This is shown on table 7.

Table 7. Comparison of mean time for sporting activities.

\begin{tabular}{lllll}
\hline Type of school & $\overline{\mathbf{X}}$ & SD & $\mathbf{n}$ & $\begin{array}{l}\text { Test statistics } \\
\text { and P value }\end{array}$ \\
\hline Public & 87.87 & 41.27 & 282 & $\mathrm{t}=5.83 ;$ \\
Private & 62.33 & 28.86 & 105 & $\mathrm{p}=.000$, \\
\hline
\end{tabular}

\subsection{School Meal Policies}

Comparing meal policies according to school type shows a significant relationship for majority of the assessed meal policies. More respondents from public schools indicated the policy of initial medical screening for food vendors, accessing the appearance of food and ensuring that varieties of food is provided for pupils by food vendors than those from private schools. The result is shown in table 8 . 
Table 8. Participants responses on availability of meal policies in school based on school types.

\begin{tabular}{llll}
\hline Meal Policies & Public n (\%) & Private n (\%) & Level of significance \\
\hline Initial Medical screening for Food Vendors & & & \\
Yes & $227(80.5)$ & $57(54.3)$ & $\mathrm{x}^{2}=26.91$ \\
No & $55(19.1)$ & $48(45.7)$ & $\mathrm{df}=1$ \\
$\begin{array}{l}\text { Routine medical examination for food vendors } \\
\text { Yes }\end{array}$ & $113(40.1)$ & $40(38.1)$ & $\mathrm{X}=2.33$ \\
$\begin{array}{l}\text { No } \\
\text { Assessing the appearance of Food provided by }\end{array}$ & $169(59.9)$ & $80(61.9)$ & $\mathrm{df}=1$ \\
food vendors & & & $\mathrm{p}=.874$ \\
$\begin{array}{l}\text { Yes } \\
\text { No }\end{array}$ & $251(89.0)$ & $68(64.8)$ & $\mathrm{x}=31.053$ \\
$\begin{array}{l}\text { Ensuring that varieties of foods Is provided by } \\
\text { food vendors }\end{array}$ & $31(11.0)$ & $37(35.2)$ & $\mathrm{df}=1$ \\
Yes & & & $\mathrm{p}=.000^{*}$ \\
No & $254(90.1)$ & $67(63.8)$ & $\mathrm{x}=37.302$ \\
\hline
\end{tabular}

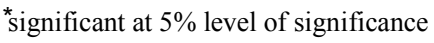

\section{Discussion}

The practice of integrating nutrition education into other subjects especially home economics, agricultural science, physical and health education in the schools examined is consistent with a study in Lagos, Nigeria which reported that majority of primary school teachers who taught nutrition did so by integrating it into other subjects in the curriculum ${ }^{[19]}$. The mean average time spent on nutrition education per week was $93.43 \pm 51.33$ minutes, when projected, it is found to be less than the recommended minimum time of 15 hours for teaching nutrition education per academic term ${ }^{[19]}$. This might has resulted from the present policy of integrating nutrition education into other subjects in the curriculum rather than being a standalone subject. A study on 12-15 hours of nutrition education per academic term showed a small, but significant positive effect on health outcomes. Larger consistent effects on health outcomes were seen when nutrition education programs were provided for between 30 50 hours, this suggested that successful lifestyle change requires significant time on teaching and translating health messages into new behaviours ${ }^{[20,21]}$. Insufficient time as a barrier to effective nutrition education within the studied school system was also consistent with a previous study which reported that teachers often had limited time to enable them to effectively teach nutrition ${ }^{[19]}$.

Likewise, other studies identified lack of time and resources; as key barriers for offering nutrition education in schools ${ }^{[22,23]}$. School curricula are generally overcrowded and dominated by exams, nutrition education is often limited and covered only briefly in the home economics syllabus. School- based nutrition education can make a vital contribution to healthy eating and therefore it is required that enough time be dedicated to it ${ }^{[1]}$.In order to achieve the target of using schools as an avenue for teaching basic hygiene and nutritional facts to learners - which is one of the objectives of the school feeding component of the School Health Program; it is essential that adequate time be allocated to nutrition education; this can be achieved by making nutrition education a standalone subject in the school curriculum

It is well established that regular physical activity is vital for healthy growth and development in children ${ }^{[24]}$, and is associated with a longer and better quality of life and has many psychological and emotional benefits ${ }^{[25]}$. The finding from the physical education world-wide summit confirmed a decline of physical activities in many school with perceived deficiencies in time allocation and material resources, and that, many schools were not able to engage their pupils in the recommended minimum sport activities of 120 minutes per week ${ }^{[26]}$. This is corroborated by the findings from the present study in which pupils spent $80.9 \pm 39.9$ minutes on sport activities per week, and in which only a smaller percent, $81(20.9 \%)$ of the respondents express total satisfaction with the level of sport activities. The implication of this is that children in the studied schools were denied the opportunity of enjoying the lifelong benefits derived from engaging in adequate physical activities. Since, physical education is taught as a separate subject in primary school, there is a need to ensure that pupils at schools engage in adequate sport activities. This is to meet the "health of the nation targets" which includes that students should take part in physical activity for at least $50 \%$ of lesson time ${ }^{[12]}$.

Another study on school meals policy indicated that more private schools $20.2 \%$ than public ones $16.5 \%$ conduct medical screening for food vendors ${ }^{[27]}$. This is contrary to the present study, which found more public schools $80.5 \%$ than private ones $54.3 \%$ to have the practice of initial medical examination for food vendors prior to being employed, although not all followed up with routine medical examination for these food vendors. Previous studies in Nigeria had shown that food vendors still exhibit a number of health hazards ${ }^{[28]}$ and also serve as sources of food borne disease outbreak and contamination to school children ${ }^{[29,30]}$. This finding indicates that majority of pupils in the study location especially those in the private schools are exposed to public health hazard through consumption of food from unscreened food vendors. Therefore, there is a need to improve on this practice to prevent school children against such public health hazard.

Presently, not all school children purchase food from food 
vendors but to ensure the demonstration of healthy eating to pupils and the aspect of the school health program which aim at providing learners with a daily supplementary meal that will improve their health and nutritional status for effective and sound learning achievement; children should be allowed the opportunity of eating at least a meal in school. This can be provided at a subsidized rate or free of charge.

The execution of our study despite its strength also had some limitations. Teacher's responses about their work activities are sometimes termed as been biased or not totally true. However, requesting the visual confirmation of some materials to buttress the facts helped to minimize this considerably where applicable.

\section{Conclusion and Recommendation}

These findings attest to a lot of deficiencies in the teaching method, time allocation, material resources for both nutrition and physical education and also in meal policies. This suggests a harmful synergy and might be a hindrance to the role of schools in using these effective and economic interventions in preventing malnutrition in children of the studied schools. Embedding nutrition information into other courses might affect the key elements of an effective nutrition education program which for this study includes adequate time, adequate funding, availability of teaching aids, established meal policies within the school environment.

For Nigerian primary schools to serve as an effective setting for the prevention of malnutrition in children and generally to achieve the overall goal of the School Health Program which is to ensure that school children achieve maximum physical and sound health which will enable them benefit maximally from their education; it is recommend that educational stakeholders should ensure that there is improved funding and planning for nutrition and physical education. The dedication to children's health is an investment that not only cannot be undermined, but also is represented as one of the highest priorities. To invest in healthy educated children is to invest in the future and advancement of a nation.

It is recommended that longitudinal studies using interventions in form of nutrition and physical education; and which takes into cognisance the above key element, be carried out in a population of poor economic resources whose children are at risk of malnutrition. This is to substantiate the available data on the economic advantage and effectiveness of using nutrition and physical education for the prevention of malnutrition in school aged children.

\section{Authors Contributions}

Adu M.D: Conceived and implemented the study, participated in data acquisition and analysis. Drafted the manuscript and gave critical contribution in the review of the manuscript.

Ajayi I.O: Participated in data analysis and interpretation and gave critical intellectual contributions in the review of the manuscript.
Adu K.T: Participated in data collection, preliminary analysis and report and gave critical contribution in the review of the manuscript. All authors read and approved the final manuscript.

\section{Acknowledgement}

The authors appreciate the head teachers in all the schools where data were collected and teachers who responded to the questionnaire.

\section{References}

[1] Food and Agricultural Organisation. Nutrition Education in Primary Schools. The Reader: 2005 Volume 1. Rome: FAO. Available at: http://www.fao.org/3/a-a033e.pdf.

[2] Akanni NA, Nkanginieme KEO, Oruamabo RS. The School health programme: A situational revisit. Nig J Paediatr; 28(1):1-6.

URL:http://www.ajol.info/index.php/njp/article/download/120 $46 / 15132$

[3] Kann L, Telljohann Sk, Wooley SF. Health Education: Results from the School Health Policies and Programs Study. J Sch Health 2006; 77(8):408-34.

[4] Bauer KW, Yang \&Austin SB.. "How can we stay healthy when you're throwing all these in front of us?" Findings from the focus groups and interviews in middle schools on environmental influences on nutrition and physical activity. Health Edu \& Behav 2004; 31(1):34-46. Doi: 10.1090198103255372

[5] Bandura A (1986). Social foundations of thought and action. Englewood Cliffs. NJ: Pretence Hall

[6] Bronfenbrenner, 1979. The ecology of human development. Experiment by nature and design. Cambridge, Ma: Havard University Press.

[7] Lytle LA, Murray DM, Perry CL, Story M, Birnbaum AS, Kubik MY, Varnell. School -Based Approaches to Affect Adolescents'Diets: Results from the TEENS Study. Health Edu and Behav 2004; 31(2):270-87.

[8] David DM, Kimiywe JO, Waudo JN \& Orodho JA. Promotion of nutrition education interventions in rural and urban primary schools in Machakos district, Kenya. Journal of Applied Biosciences 2008; 6:130-139. Available at: http://m.elewa.org/JABS/2008/6/1.pdf. Accessed 4 may, 2010.

[9] Physical Education Association of the United Kingdom. PEA UK Policy on the Physical Education Curriculum 2004. Available at: http://www.pea.uk.com/menu.html; Accessed $16^{\text {th }}$ June, 2015.

[10] Zeigler,E. Physical education's and principal principles. Journal of Physical Education, Recreation and Dance 1994; $65: 4-5$.

[11] Concento JR, Randell JS, Basch CE. Review and analysis of evaluation measures used in nutrition education research. $\mathrm{J}$ Nutr Educ Behav 2002; 34:2-25. 
[12] U.S. Department of Health and Human Services 2001. The Surgeon General's Call to Action to Prevent and Decrease Overweight and Obesity. Rockville, Md.: U.S. Department of Health and Human Services, Public Health Services, Office of the Surgeon General.

[13] Ene-Obong H, Ibeanu V, Onuoha N, Ejekwu A 2012. Prevalence of overweight, obesity, and thinness among urban school-aged children and adolescents in southern Nigeria. Food \& Nutrition Bulletin: Nevin Scrimshaw International Nutrition Foundation (Eds) 2012; 33(4), 242-250(9).

[14] Senbanjo IO and Oshikoya KH. Physical activity and body mass index of school children and adolescents in Abeokuta, South West Nigeria; World J Pediatr2010; 6(3), 217-222.

[15] Available at http://link.springer.com/article/10.1007/s12519010-0209-9\#page-2.

[16] Idehen CO, Oshodin OG. Factors affecting health instruction in secondary schools in Edo State. Ethno med.2008; 2(1): 6166 .

[17] Vander VS. Primary school health: "where are we going?" Realities in the life of school children in the third world. Hygie XI; 1992/3: 45-9.

[18] Ojugo AI. Status of health appraisal services for primary school children in Edo State, Nigeria. International Electronic Journal of Health Education 2005; 8:146 -152.

[19] Nigerian Education Research and Development Council (2008). The 9-year Basic Education Curriculum at a glance. Lagos, NERC Press.

[20] Bonike Odegbami, Bukky Onigbogi, Dotun Akinadewo (2003).Nutrition Education Needs at Expressway Primary School: Establishing Priorities. Available at:

[21] www.naijatek.com/clients/ProjectPromise/pdf/NutritionEducat ion.pdf

[22] Concento I, Balch GI, Bronner Y.L. The effectiveness of nutrition education and implications for nutrition education policy, programs and research: a review of research. J Nutr Educ. 1995; 27: 250-260.
[23] Olander C. Nutrition education and the role of dosage. Alexandria, VA: US. Department of Agriculture, Food and Nutrition Service; 2007. Available at: http://www.fns.usda.gov/sites/default/files/LitReview_Dosage .pdf

[24] U.S. Department of Agriculture. The Food Guide Pyramid Centre for Nutrition Policy and Promotion. Home Garden Bulletin, 1992; 252.

[25] Friedman G, Kushner R, Alger-Mayer S et al., Proposal for medical school nutrition education: Topics and recommendations. J Parenter Enteral Nutr November 2010:34(suppl):405-465.

[26] Janssen I, Leblanc AG. Systematic review of the health benefits of physical activity and fitness in school-aged children and youth. Int J Behav Nutr Phys Act. 2010;7:40

[27] Sallis J. and Owen, N. Physical Activity and Behavioural Medicine. Thousand Oaks, CA: Sage Publication Inc; 1999

[28] Hardman K and Marshall J. The state and status of physical education in schools in international context. Eur. Phys. Educ. Rev. 2000; 6:203- 229

[29] Ofovwe GE and Ofili AN. Knowledge, Attitude and Practice of School Health Programme among Head teachers of Primary Schools in Egor Local Government of Edo State, Nigeria. Ann Afr Med 2007; 6:99-103. Available at: http://www. Annalsafrmed.org/text.asp?2007/6/3/99/55726. Doi: $10.4103 / 1596.55726$

[30] Chukuezi CO. Food safety and Hygiene Practices of Street Food vendors in Owerri, Nigeria. Stud Sociol Sci 2010; 1 (1): $50-7$

[31] Idowu OA, Rowland SA. Oral fecal parasites and personal hygiene of food handlers in Abeokuta, Nigeria. Afr Health Sci. 2006; 6(3):160-4

[32] Mensah P,Yeboah-Manu D, Kwaku O and Ablordey. A. Street foods in Accra, Ghana: how safe are they? Bull World Health Organ; 2002; 80(7): 546 - 554. ISSN 0042-9686. Available from: http://www.dx.doi.org/10.1590/s0042-96862000700006 